\title{
Creation, World-Actualization, and God's Choice Among Possible Worlds
}

Klaas J. Kraay

Ryerson University

Kraay, K. J. (2008). Creation, actualization and God's choice among possible worlds. Philosophy Compass, 3(4), 854-872.

doi:10.1111/j.1747-9991.2008.00159.x

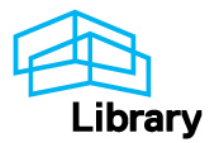




\title{
Creation, Actualization, AND God’s Choice among Possible Worlds
}

\author{
Klaas J. Kraay \\ Ryerson University
}

This paper appears in Philosophy Compass 3 (2008): pp. 854-72. The published version can be found online at: http://onlinelibrary.wiley.com/doi/10.1111/j.1747-9991.2008.00159.x/pdf

God is traditionally understood to be a perfect being who is the creator and sustainer of all that is. God's creative and sustaining activity is often thought to involve choosing a possible world for actualization. It is generally said that either there is (a) exactly one best of all possible worlds, or there are (b) infinitely many increasingly better worlds, or else there are (c) infinitely many unsurpassable worlds within God's power to actualize. On each view, critics have offered arguments for atheism that turn on God's choice of a world. In what follows, I first discuss some background issues, and I then survey the contemporary literature on these arguments.

Traditional versions of Judaism, Christianity, and Islam maintain that God is a perfect being. Famously, Anselm understood this doctrine to mean that God is a being than which none greater is conceivable. If conceivability does not exhaust possibility, a more robust expression of this doctrine holds that God is a being than which none greater is possible. Proponents of this view often say that God is a necessary being who is essentially unsurpassable with respect to various attributes, such as power, knowledge, goodness, and wisdom.

God is also taken to be the creator and sustainer of all that is. This is sometimes thought to involve an initial act of creation ex nihilo, followed by the continued conservation in existence of all the things there are. There are many philosophical puzzles for theism here. ${ }^{1}$ One might wonder how an incorporeal, immaterial being can bring about physical effects at all. One might further wonder how such a being can bring about such effects ex nihilo. ${ }^{2}$ Relatedly, since God is sometimes taken to exist outside of time, one might wonder how a timeless being can bring about temporal effects. 3 In addition, there are questions about what might be involved in sustaining things in existence. 4 There are further questions about whether such a being can be understood to intervene in the course of nature. 5 And there are questions about the relationship between God and non-physical existents (such as numbers, sets, and the like), ${ }^{6}$ and necessary truths.7

In what follows, I set these issues aside, in order to concentrate on a set of issues pertaining to God's choice in creation. In contemporary analytic philosophy of religion, this choice is construed as follows: God surveys the set of possible worlds, and then freely chooses exactly one for actualization ${ }^{8}$ on the basis of its axiological properties. This suggests that possible worlds can sensibly be thought to bear axiological properties. In Section 1, I offer a brief account of these. To properly consider God's choice of a world, something must be said about the array of worlds from which God is said to choose. So, in Section 2, I describe the three standard hierarchies in the literature: either there is (a) exactly one unsurpassable world, or there are (b) infinitely many increasingly better worlds, or else there are (c) infinitely many unsurpassable worlds. After clarifying what is meant by world-actualization in Section 3, I discuss each of these three hierarchies. Arguments for atheism have been offered on each, and, in Sections 4-6, I survey the contemporary discussion of these arguments on each hierarchy, in turn. 


\section{Possible WorldS AND THeir AXiOlogicAl PROPERTIES}

Discussions of God's choice of a world typically assume that worlds have axiological status, and that they can (at least in principle) be evaluated: some are good, others are bad; some are better, others are worse. Here is one way to understand this. Whether possible worlds are taken to be concrete objects, abstract objects, or convenient fictions, it seems plausible to suppose that, if actual, they can properly be said to bear world-good-making properties (hereafter WGMPs). These are properties which, ceteris paribus, tend to make worlds good. 9 Similarly, it is reasonable to suppose that there are world-bad-making properties (hereafter WBMPs). ${ }^{10}$ On this account, the axiological status of a world can be understood to depend upon which WGMPs and WBMPs are instantiated in the world, and the degree to which they are exemplified. ${ }^{11}$

To simplify matters, let's assume necessitarianism: the actual set of WGMPs and WBMPs could not possibly have had different members than it does. ${ }^{12}$ And let's assume, again for simplicity, that all worlds are both commensurable and comparable with respect to these properties. ${ }^{13}$ Finally, in what follows I restrict my focus to divinely-actualizable worlds. While it is tempting to assume that every possible world is capable of actualization by God, Alvin Plantinga has persuasively argued that this is false. ${ }^{14}$ While I will not always explicitly qualify my discussion below to indicate this restriction, it should be presumed.

\section{THREE HIERARCHIES OF ACTUALIZABLE WORLDS}

These axiological considerations suggest that there are three candidate hierarchies of divinelyactualizable worlds worth considering:

(a) Famously, Leibniz held that there is exactly one unsurpassable world. (Hereafter, I'll call this view EOUW.) ${ }^{15}$

(b) Other philosophers, following Aquinas, ${ }^{16}$ have suggested instead that perhaps there simply is no best actualizable world, but rather an infinite hierarchy of increasingly better worlds. ${ }^{17}$ (Hereafter, I'll call this position NBW.)

(c) Still other philosophers have held that there are multiple unsurpassable worlds. ${ }^{18}$ This view is generally supported by the thought that for any world $\mathrm{w}$ having axiological status $\mathrm{s}$, there is a trivially different variant, $\mathrm{w}^{\prime}$, that also has axiological status S. ${ }^{19}$ Moreover, it is often thought that there are infinitely many such variants. On this view (hereafter IMUW), there are infinitely many unsurpassable worlds.

Clearly, these three hierarchies are mutually exclusive. I further assume that they are jointly exhaustive. ${ }^{20}$ In Section 3, I clarify what is meant by world-actualization. I then canvass several important objections to theism on each of these hierarchies, respectively (Sections 4-6).

\section{WORLD-ACTUALIZATION}

Some clarifications about world-actualization are in order. When God selects a world for actualization, God causes it to be the case that one world rather than another is actual. It is tempting to imagine that, in so doing, (a) God stands outside the set of possible worlds; that (b) God always creates something; and that (c) God determines each and every feature of the ensuing world (d) all at once. The first two assumptions are false, and the latter two are dispensable on theism. 
Theists often take God to be a necessary being: one who could not possibly fail to exist, or, equivalently, one who exists in all possible worlds. On this view, no sense can be made of the idea that God stands outside of the set of worlds in order to select one for actualization. Since the possible worlds there are exhaust the way things could be, there simply is no vantage point, divine or otherwise, outside this set.

Second, while it is tempting to conflate world-actualization and creation, it is important to keep these distinct. Creation occurs when God causes it to be the case that some spatiotemporal entity is actual, but not every instance of world-actualization need involve this. Suppose that God creates nothing. If so, there still is an actual world. We might call it the bare world, since it is empty - save for whatever uncreated existents (such as numbers and God) it contains. God, of course, is responsible for this world's being actual, and so God has actualized it, without creating anything at all. This suggests that while God may be free to refrain from creating, God is not free to refrain from actualizing a world.

Third, God's actualizing a world need not mean that he determines each and every feature of the resulting world. Consider, for example, random processes. If a world features such processes, God causes it to be the case that they occur, but he does not (by definition) determine their outcome. Next, consider libertarian freedom. Many theists maintain that human beings have such freedom, and that the free choices of such creatures affect how the world unfolds (at least in worlds which feature such creatures). On this view, God and these creatures jointly actualize a world: both play a role in determining which world is actual. God is responsible for a world's being the way it is prior to the introduction of creatures, and God is also responsible for the introduction of those creatures: all this properly counts as the product of God's worldactualizing activity. But when such creatures are introduced and act freely, they help make it the case that one world rather than another is actual, and such determinations count as the product of their world-actualizing activity, not God's. The resulting world is partly the product of God's actions, and partly the product of creaturely actions. ${ }^{21}$

Finally, there is no need to suppose that God's causal activity in actualizing a world is limited to one act at the 'beginning' of that world. Some theists hold that God intervenes from time to time. On this view, divine interventions help make it the case that one world rather than another is actual, and, accordingly, God can properly be said to perform world-actualizing actions throughout the history of the world being actualized. In addition, as noted, many theists hold that God's world-actualizing activity includes sustaining whatever is actual. This also suggests that God's world-actualizing activity does not occur 'all at once' at the outset of a world.

\section{OBJ ECTIONS TO THEISM ON EOUW}

On EOUW it has been urged, a priori, that a perfect being will actualize the unique best possible world. This idea recurs throughout the history of philosophy. Particularly clear expressions of it are found in Plato's Timaeus, ${ }^{22}$ in Leibniz' Theodicy, ${ }^{23}$ and in Kant's Lectures in Philosophical Theology. ${ }^{24}$ The basic claim is that for God to select a world other than the best possible would be a failure of either goodness, or wisdom, or both - and neither is acceptable for an unsurpassable being.

Robert Adams (1972) rejects the view that God must actualize the best possible world. He concedes that act-utilitarianism suggests this view, but he rightly notes that the JudeoChristian ethical tradition is not typically utilitarian. He proposes to show that theists can reasonably reject this view. To do this, he offers two candidate reasons for it, and then suggests that neither is persuasive: 
(Q) A creator would necessarily wrong someone (violate someone's rights), or be less kind to someone than a perfectly good moral agent must be, if he knowingly actualized a less excellent world instead of the best that he could.

(R) Even if no one would be wronged or treated unkindly by the actualization of an inferior world, the creator's choice of an inferior world must manifest a defect of character.

Against (Q), Adams claims that it is plausible to suppose that God could actualize a world with the following characteristics:

(S) None of the individual creatures in it would exist in the best of all possible worlds;

(T) None of the creatures in it has a life which is so miserable on the whole that it would have been better for that creature if it had never existed; and

(U) Every individual creature in the world is at least as happy on the whole as it would have been in any other possible world in which it could have existed.

Adams thinks it obvious that God wrongs no one by actualizing a world with these characteristics, and he suggests that God need not be less than perfectly kind to someone in so doing. Against (R), Adams claims that - far from manifesting a defect of character - God's choice of an inferior world can manifest the Judeo-Christian virtue of grace, which he defines as "...a disposition to love which is not dependent on the merit of the person loved" (97-8).

Adams' rejections of both $(\mathrm{Q})$ and $(\mathrm{R})$ have not been well-received. With respect to (Q), Michael Levine argues that “...the criterion of personal identity Adams' argument rests upon is both stipulative and counterintuitive" (1996, 31). David Basinger grants Adam's assumptions concerning personal identity, but insists that even if God actualizes a world with characteristics (S), (T), and (U), it may still be the case that God wrongs individuals in that world (1983). ${ }^{25}$ With respect to (R), many authors have criticized Adams' appeal to grace. Most of these object either to Adams' understanding of this virtue or its application to this issue (e.g. Basinger 1983; Thomas 1996; Gale 1998; Grover 2003). In contrast, Erik Weilenberg suggests that even if God exhibits the virtue of grace in actualizing a world other than the best, God also exhibits the absence of a different virtuous trait: the disposition to pursue intrinsically valuable states proportionally (2004, 51-2). As such, God's action in selecting a world other than the best would manifest a defect of character, just as (R) says.

Even if none of these objections is decisive, further considerations show that Adams' argument cannot achieve its stated goal. William Rowe says:

As forceful and persuasive as Adams' arguments are, I don't think they yield the conclusion that God's perfect goodness imposes no requirement on God to create the best world that he can create. What Adams's argument show, at best, is that God's moral perfection imposes no moral obligation on God to [actualize] the best world he can. His arguments establish, at best, that God need not be doing anything morally wrong in [actualizing] some other world than the best world. But this isn't quite the same thing as showing that God's perfect goodness does not render it necessary that he [actualize] the best world he can $(1993,228$, and see 2004, 82)

Rowe holds that if God fails to actualize the best possible world, then God's action in so doing is surpassable. And, presumably, if God's action is surpassable, then God is surpassable (1993, 2004). Others have held similar views, either with respect to morality or rationality. ${ }^{27}$ In what follows, then, I will treat the traditional position as correct: if there is a unique unsurpassable world, God will actualize it. 


\subsection{The PROBLEM OF EVIL}

Given this position, perhaps the most obvious criticism of theism on EOUW holds that the actual world is surpassable. When this claim is supported by a posteriori premises about the existence, nature, scope, duration, or distribution of suffering, this objection belongs to a family of arguments known as the problem of evil. ${ }^{28}$

Arguments from evil can be divided into the more ambitious (those that attempt to show that God does not exist ${ }^{29}$ ) and the more modest (those that attempt to show only that probably God does not exist. ${ }^{30}$ ) Arguments of the former sort typically involve (or entail) an a posteriori claim to the effect that the actual world is surpassable; arguments of the latter sort typically involve (or entail) an a posteriori claim to the effect that the actual world is probably surpassable. Such claims are in turn defended by appeal to examples of moral evil (suffering caused by free moral agents) or natural evil (suffering not caused by such agents33). It is often claimed that some instance of this evil is gratuitous: eliminable by God without thereby either (a) permitting an equal or worse evil, or (b) preventing a greater good. Most participants in the discussion assume that the presence of any gratuitous evil in the actual is indeed inconsistent with the existence of God, but a minority of theists have resisted this claim. 34 Generally, though, defenders of theism respond to such arguments by contending that the proffered instance of evil has not been shown to be gratuitous, or probably gratuitous. This discussion is very lively in the contemporary literature, and a survey of it is beyond the scope of this paper.

\subsection{The Problem Of Modal Collapse}

I have suggested that an unsurpassable being will select the unique best world for actualization on EOUW. But if this is so, critics have urged, it seems that no other world could be actual. This suggests that on theism and EOUW, modal collapse ensues: no other world is possible, in which case everything in the actual world is necessary - nothing could be otherwise than it is. This consequence is briefly noted in Gale (1991, 31-32), Garcia (1992, 204), Wainwright (1996, 127), and Wierenga $(2007,208)$, and more developed arguments in this vein are offered by Resnick (1973) and Heller (1999). Since this consequence unduly violates our modal intuitions and judgments, some argue, theism should be rejected instead. 35

\subsection{The Problem of Divine FreEdoM}

Theists generally assert that God's decision to create is a free one. ${ }^{6}$ In the contemporary literature, this thought is extended to the claim that God's selection of a possible world to actualize is free. But on EOUW, if it is the case that God cannot but select the unique unsurpassable world, it seems to follow that God is unfree.

Much depends, of course, on whether the possibility of doing otherwise is essential for freedom. Rowe $(1999,2002)$ believes that it is, and offers detailed criticisms of the efforts of Leibniz, Clarke, and Edwards to maintain divine freedom on EOUW (2004). But there have been dissenters. Wainwight holds that "compatibilist notions of freedom are more plausible with respect to God than creatures" $(1996,127)$, and several other authors have offered accounts of how God can properly be said to freely select the unique unsurpassable world, even if no other course of action is possible. 37

The literature on the problem of divine freedom on EOUW is not yet large, and it is safe to say that the diversity and complexity of philosophical positions on free will is not yet adequately reflected in it. But this discussion is closely connected to a large body of recent published work on the more general question of whether God has the power to sin. If God is omnipotent, some argue, God has the power to sin. And having the power to sin, some say, entails that, possibly, God sins. On the other hand, some argue that divine impeccability 
precludes the possibility that God sins..$^{8}$ Moves and countermoves from this discussion can be applied, mutatis mutandis, to the question of whether God can properly be said to freely select the unique best world on EOUW.

\subsection{The Problem of ThanKS AND Praise}

Finally, it is worth noting that the problem of divine freedom seems to suggest a further worry: the problem of thanks and praise. Rowe (2004) argues that if God is not free on EOUW, then it is unreasonable for theists to consider God a proper object of thanks and praise. But this poses a problem for theists, since they typically take God's creation (and hence God's choice of a world to actualize) to be paradigmatically worthy of thanks and praise. In response, Senor (2008) concedes that on this view, perhaps God is not morally praiseworthy. But he urges that God is still properly praised for who he is, and properly thanked for what he has done. Relatedly, Bergmann and Cover (2006) suggest that God can properly be thanked, even in the absence of divine freedom.

\section{OBJ ECTIONS TO THEISM ON NBW}

\subsection{THE PROBLEM OF EVIL}

On NBW, it is no longer reasonable to demand that God select an unsurpassable world for actualization: since there is no such thing, this is an impossible task, and hence cannot properly be demanded of God. Some have thought that NBW inoculates theism entirely from the problem of evil (Schlessinger 1977), but this has not been well-received.39 Others have argued, against theism, that God ought to have actualized a better world than ours, even if no best world is available (Perkins 1983; Chrzan 1987; Elliot 1993). The moves and countermoves in this discussion on EOUW can generally be made, mutatis mutandis, on NBW.

\subsection{THE PROBLEM OF No BEST WORLD}

In recent years, philosophers have suggested on purely a priori grounds that NBW, together with some plausible principles concerning improvability, logically precludes the existence of an unsurpassable being. (This argument is advanced in various ways by Grover 1988, 2003, 2004; Rowe 1993, 1994, 2002, 2004; Sobel 2004, 468-479; and Wielenberg 2004). The core of this argument can be expressed with reference to the following inconsistent set of propositions:

NBW For every world $w$ that is within God's power to actualize, there is a better world, x, that God has the power to actualize instead.

P1 If it is possible for the product of a world-actualizing action performed by some being to have been better, then, ceteris paribus, it is possible for that being's action to have been (morally or rationally) better.

P2 If it is possible for the world-actualizing action performed by some being to have been (morally or rationally) better, then, ceteris paribus, it is possible for that being to have been better.

G There possibly exists a being who is essentially unsurpassable in power, knowledge, goodness, and rationality. 
Critics of theism urge that since this set is inconsistent, and since P1 and P2 are plausible, defenders of NBW ought to reject G. This amounts to an a priori argument for the impossibility of an essentially unsurpassable God on NBW, and has come to be called the problem of no best world. $4^{40}$

\subsection{Five Theistic ResPonses to the Problem of No BeSt World}

In this section, I briefly survey five broad ways in which the theist might respond to the problem of no best world. First, of course, the theist can evade the argument by rejecting NBW. Grover (1988, 1999) recommends reverting to the EOUW, but, as noted in Section 4, there are drawbacks to this move. Alternatively, the theist could endorse IMUW, but there are difficulties with this position too, as will be outlined in Section 6 .

Second, the theist might adopt the purely defensive ploy of attempting to undercut or rebut the support for $\mathrm{P}_{1}$ and $\mathrm{P}_{2}$ proffered in the literature. Rowe (2004, Chapter 6) defends these claims, although they are conflated in his Principle B:41

If an omniscient being [actualizes] a world when there is a better world that it could have [actualized] then it is possible that there exists a being morally better than it $(2004,4)$.

Rowe supports Principle B with a parity argument: he chides theists who assume or endorse this principle when they claim that God must actualize the unique best world on EOUW, but then reject it on NBW $(2004 ; 120-1,124-5)$. Interestingly, Rowe also suggests that this principle is "plausible, if not self-evident"; that it has "intuitive appeal"; and that, on this basis alone, it should be presumed true $(89,124)$. Theists wishing to block the arguments for P1 and P2 should respond to both of these defences.

Third, the theist might try to reverse the argument: granting NBW, she might claim that $\mathrm{G}$ - a modest proposition - is better-supported than P1 and P2. How might she defend G? Of course, a good argument for the actual existence of an essentially unsurpassable deity would do, since this would establish a fortiori that such a being is possible. More modestly, she might try to show that God is possible, perhaps by urging that an essentially unsurpassable being is conceivable, and by claiming that conceivability is a reliable indicator of possibility. Or, more modestly still, she might follow Plantinga (2000) and argue that G can be a properly basic belief for the theist, given certain conditions. If any such strategy makes it more plausible to maintain $\mathrm{G}$ than $\mathrm{P}_{1}$ and $\mathrm{P}_{2}$, then this argument fails.

Fourth, the theist might sacrifice her commitment to essential divine unsurpassability (in other words, deny G). She might concede that $\mathrm{G}$ is precluded by the conjunction of $\mathrm{P} 1, \mathrm{P} 2$, and NBW, and grant that the latter three are plausible. But she might then construct an account of divine perfection that does not involve essential divine unsurpassability, or some other notion of God altogether. (See Kraay 2005, 30-2; Wainwright 2005, 18.) This move is unlikely to please most traditional monotheists, however, since they typically consider essential divine unsurpassability to be non-negotiable.

Finally, of course, the most natural response for the theist is to attack P1 or P2 directly. This may take one of two forms: it might be suggested that their conjunction is unmotivated (or defeated) by reflection on human cases, or it might be alleged that their conjunction is implausible in the divine case. Arguments against P1 may be found in Langtry (1996, 2006); Leftow (2005a and 2005b); Wierenga (2007); and Daniel and Francis Howard-Snyder (1994, 1996). Arguments against P2 may be found in Morris (1993) and Hasker (2004a, 2004b, 2005). A considerable literature has grown around these arguments, and space prevents surveying it here. But for a more detailed guide to this terrain, see Kraay ('The Problem of No Best World', forthcoming). 


\section{OBJ ECTIONS TO THEISM ON IMUW}

In Section 4, I urged that if there is exactly one unsurpassable world, God will select it for actualization. This thought can be applied to IMUW: on this hierarchy, God will select one member of the infinite set of unsurpassable worlds for actualization. Some of the objections to theism on EOUW can be deployed on IMUW: I discuss these briefly in Section 6.1. And there is a further objection to theism on IMUW, to which I turn in Section 6.2.

\subsection{The Problems of Evil, Modal Collapse, Divine Freedom, and Thanks and Praise}

In Section 4, I outlined various objections to theism on EOUW: the problems of evil, modal collapse, divine freedom, and thanks and praise. Each of these can be pressed, mutatis mutandis, against theism on IMUW.

(a) Arguments from evil can allege, on a priori grounds, that God will choose one member of the set of unsurpassable worlds for actualization on IMUW, and, on a posteriori grounds, that this expectation has not (or probably has not) been met, since the actual world is (or probably is) surpassable.

(b) Proponents of the argument from modal collapse can suggest that on IMUW, surpassable worlds turn out to be impossible, contrary to our best modal intuitions and judgments.

(c) Some philosophers (like Swinburne 1979, 114-5 and Flint 1983) argue that the idea of multiple unsurpassable worlds preserves God's freedom: even though God cannot select a surpassable world for actualization, God has great freedom in choosing one from the set of unsurpassable worlds. But dissenters (such as Fales 1994, 69; and Wierenga 2002, 433) maintain that this is not an adequate defence of divine freedom. Such critics regard God's choice of a world on IMUW as unacceptably arbitrary, and hence not significantly free.

(d) Finally, one might suggest that if God cannot fail to select an unsurpassable world for actualization, God cannot properly be thanked and praised for selecting such a world over the surpassable alternatives. Further, one might claim that God cannot properly be thanked and praised for his (arbitrary) selection of any particular unsurpassable world over the other unsurpassable alternatives. ${ }^{2}$

\subsection{THE PROBLEM OF PARALYSIS}

It has been claimed, on a priori grounds, that IMUW precludes theism. If there are infinitely many unsurpassable worlds, God would not have sufficient reason to actualize any particular one. And this, in turn, would lead to "paralysis of the divine motivational system," which is inimical to theism (Blumenfeld $(1975,172) .43$ It is sometimes thought that the problem for theism here is this: granting that God could have no principled reason for selecting any particular world in these scenarios, God would be paralyzed, stymied, or hamstrung - unable to actualize any world. This is a mistake. As noted in Section 3, God cannot fail to actualize some world or other. The problem is not that God - while existing - is somehow frustrated in his desire to actualize a world. The problem is much more serious: if God must have a sufficient reason for selecting a world to actualize, then IMUW is logically incompatible with theism.

In response, philosophers have denied that God must have a sufficient reason for selecting a world to actualize on IMUW. They point out that in ordinary human affairs, when rational choice is thwarted by the absence of sufficient reasons, practical considerations render it reasonable for us to choose at random.44 These philosophers urge that God may do the same, while remaining unsurpassable in all relevant respects. 45 If this is defensible, then the objection to theism on IMUW is defanged. 
Lloyd Strickland (2006) offers such an argument. In offering randomization as a solution to the problem of choice among many unsurpassable worlds, however, Strickland also introduces the problem of choice among many randomizers. Strickland asserts without argument that (a) there are multiple randomizers, and that (b) at least some (and perhaps all) are unsurpassable $(2006,153)$. Let's consider each claim in turn.

A randomizer is a device or procedure that delivers a random output. Why think that there is more than one randomizing device or procedure on IMUW? Randomizing devices are presumably physical objects which output a random number. It is well known that there are numerous indeterministic features or processes in the actual world. Accordingly, theists should not find it difficult to imagine that God could construct a variety of indeterministic devices to generate random numbers. ${ }^{46}$ Moreover, devices could perhaps be combined in various ways to generate new devices. As for non-physical randomization procedures, if there are any, there are many. The reason is simple: for any randomization procedure $r$, it's possible to construct a different randomization procedure $s$ which uses $r$, and then performs a mathematical operation on the deliverances of $r$ to generate a new result. Perhaps, for example, $s$ takes the result of $r$ and adds one (or indeed any other number). This new result is every bit as random as the deliverances of $r$, although the procedure is different. Finally, hybrids seem possible: combinations of devices and procedures. Accordingly, it seems extremely plausible to grant that there is more than one randomizer on IMUW.

I now turn to Strickland's second undefended claim: that some randomizers are unsurpassable. How might one defend this? Randomizers, like other things, are presumably to be evaluated with respect to their axiological properties - their good-making and bad-making properties. 47 To show that some (or all) randomizers are unsurpassable, Strickland requires an account of what these properties are, and a reason for thinking that they can be unsurpassably exemplified. But it is very difficult to say what these are for randomizers, and how they might work together to determine the axiological status of a randomizer. ${ }^{48}$ Accordingly, it is far from clear that Strickland is entitled to assume that some - let alone all! - randomizers are unsurpassable.

The problem of choosing a world on IMUW is thus transposed into the problem of choosing a randomizer. And the scenarios on offer - one unique unsurpassable randomizer, multiple unsurpassable randomizers, or no unsurpassable randomizers - correspond to the hierarchies of worlds we have been considering. Those who are inclined to think that the problem of divine world-selection on these hierarchies is intractable are not likely to be pleased by the introduction of parallel problems of choice among randomizers. 49 


\title{
ACKNOWLEDGEMENTS
}

I am grateful to Nathan Ballantyne for comments on an earlier draft, and to an anonymous referee for several incisive criticisms and helpful suggestions.

\section{SHORT BIOGRAPHY}

Klaas J. Kraay works in metaphysics and epistemology, especially as applied to theism. He received his Ph.D. in Philosophy from the University of Toronto in 2002, and has taught at Ryerson University since 2003. He has published papers relevant to the issues discussed here in Faith and Philosophy, the International Journal for Philosophy of Religion, Philo, and Philosophia.

\author{
Klaas J. Kraay \\ Department of Philosophy \\ Ryerson University \\ 350 Victoria Street \\ Toronto, ON \\ CANADA M5B $2 \mathrm{~K}_{3}$
}

Tel: 416.979.5000 x1-6165

Email: kraay@ryerson.ca

\section{$\underline{\text { NOTES }}$}

${ }^{1}$ The puzzles listed here have, of course, been widely discussed throughout the history of philosophy. One excellent introduction to the enormous medieval discussion of such matters is Bosley and Tweedale (2006). For a bibliography of analytic work in this area between 1940 and 1996, see Wolf $(1998,437-$ 457).

${ }^{2}$ See, for example, Morris (1983); Ford (1983); Potter (1986); and Craig (1987).

3 A good introduction to the contemporary discussion of God and time is Ganssle and Woodruff (2002).

4 See Kvanvig and McCann (1988); Quinn (1983, 1993); Freddoso (1991); McCann (1997); Craig (1998); Beaudoin (2007); and Talbott (unpublished manuscript).

5 The most widely discussed topic of this sort is miracles, and the most widely discussed argument concerning miracles is due to David Hume. For a survey of the contemporary debate concerning Hume's argument, see Taylor (2007). For a bibliography of analytic work on miracles published between 1940 and 1996, see Wolf (1998, 458-473).

${ }^{6}$ See, for example, Davison (1991).

7 See, for example, Davis (2001).

8 Worlds are generally said to be actualized, rather than created. One reason is that certain influential views of modality (e.g. that of Plantinga (1974a)) hold that worlds are necessarily existing states of affairs - and such states can neither be created nor destroyed. I say more about the distinction between actualization and creation in Section 3, below. 
9 Candidate WGMPs pick out a property held to be good-making. Examples include: the presence of free moral agents in the world; the favourable balance of moral actions over immoral ones; the variety of phenomena in the world; and the simplicity of a world's governing laws.

${ }^{10}$ Candidate WBMPs typically appeal to the presence of unjustified evil or suffering in the world. On the Augustinian view according to which evil is in fact the absence of good (privatio boni), every WBMP would presumably refer to the absence of a WGMP. There may be such WBMPs, and there may also be WBMPs that are the contraries of WGMPs, and there may be other, different, WBMPs. I remain neutral on this; nothing turns on it for my purposes.

${ }^{11}$ It may be that certain good-making properties cease to make worlds better past a certain point, or in certain combinations. The same goes, mutatis mutandis, for WBMPs. So, while the goodness of a world depends on its axiological properties, this dependency may not be simple.

12 The rival view, which I call contingentism, holds that the actual set of WGMPs and WBMPs might have had different members. One version of this view, called theological voluntarism, holds that God could have willed other properties to be good-making and bad-making than the ones that are so. For a discussion of this view, see Mann (1991, 253-8).

${ }_{13}$ One might deny that all worlds can properly be evaluated with respect to a stable set of WGMPs: this is to hold that there are incommensurable pairs of worlds. (On this, see Mann (1991, 268-73), and Grover (1998).) Alternatively, one might deny that all worlds can be compared. This can be done with or without appeal to incommensurability. Incommensurable worlds, of course, cannot be compared. But even if all worlds are commensurable, there might still be failures of comparability between worlds. For simplicity, I set these niceties aside.

14 In brief, Plantinga posits that there are truths about how libertarian-free creatures would behave in various circumstances. These truths serve to restrict God's creative options, from which it follows that not every possible world is actualizable by God (1974a, 169-184).

${ }^{15}$ A very helpful elucidation of Leibniz' view may be found in Blumenfeld (1975).

${ }^{16}$ Kretzmann (1991b) offers a clear account of Aquinas' reasoning in this matter.

${ }_{17}$ See, for example, Plantinga (1974b, 61); Schlesinger (1977); Forrest (1981); Reichenbach (1982, 121-9); and Swinburne (1979, 114-5). For doubts about such claims, see Grover (1999); Franklin (2002); and Strickland (2005).

${ }^{18}$ For example, see Hoffman and Rosenkrantz (2002, 159) and Strickland (2006). Many more treat this as an epistemic possibility.

19 For example, suppose that $\mathrm{w}^{\prime}$ differs from $\mathrm{w}$ by having one more grain of sand on one beach than $\mathrm{w}$ does (and whatever is required for this, and whatever ensues from this). It seems reasonable to suppose that $\mathrm{w}$ and $\mathrm{w}^{\prime}$ are axiologically equivalent.

20 I here take for granted that there is no principled middle ground between claiming that there is exactly one unsurpassable world, and that there are infinitely many.

${ }^{21}$ Molinism is the doctrine according to which there are unalterable contingent truths (known by God) about how libertarian-free creatures would act in various possible circumstances. (See Flint (1989).) On Molinism, God can control which libertarian-free creaturely actions occur without causing them: by actualizing the world in which his favoured creaturely actions obtain. This might be thought to favour the view that God determines every feature of a world in actualizing it, and this might be desirable for theists with a robust conception of divine sovereignty. But since theism does not entail Molinism, it remains 
correct to say that theism does not require the view that God determine every feature of a world in actualizing it.

22 "God desired that all things should be good and nothing bad, so far as this was attainable. Wherefore also finding the whole visible sphere not at rest, but moving in an irregular and disorderly fashion, out of disorder he brought order, considering that this was in every way better than the other. Now the deeds of the best could never be or have been other than the fairest ..." (29E-30B).

23 Two examples will suffice:

Now this supreme wisdom, united to a goodness that is no less than infinite, cannot but have chosen the best. For as a lesser evil is a kind of good, even so a lesser good is a kind of evil if it stands in the way of a greater good; and there would be something to correct in the actions of God if it were possible to do better (128).

...God is bound by a moral necessity, to make things in such a manner that there can be nothing better: otherwise not only would others have cause to criticize what he makes, but, more than that, he would not himself be satisfied with his work, he would blame himself for its imperfection; and that conflicts with the supreme felicity of the divine nature (253).

24 "That the world created by God is the best of all possible worlds, is clear for the following reason. If a better world than the one willed by God were possible, then a will better than the divine will would also have to be possible. For indisputably that will is better which chooses what is better. But if a better will is possible, then so is a being who could express this better will. And therefore this being would be more perfect and better than God. But this is a contradiction; for God is omnitudo realitatis" (137).

25 Hasker (1984) responds; Basinger (1985) replies.

27 See Quinn (1982); Wielenberg (2004); Sobel (2004); Flint (1983); Swinburne (1979, 134); Grover (1988, 2003, 2004), and Wierenga (2002).

${ }^{28}$ An excellent collection of classic and contemporary sources on the problem of evil is Larrimore (2001). Whitney (1998) contains a list of 4300 (mostly annotated) citations of the literature published between 1960 and 1991.

29 The contemporary discussion of this argument begins with Mackie, J.L. (1955).

30 The contemporary discussion of this argument begins with Rowe (1979). An excellent anthology of subsequent work in this area is Howard-Snyder (1996).

33 For an excellent survey of the contemporary literature on such arguments, see Gelinas (forthcoming), and for an annotated bibliography of contributions to this debate between 1960 and 1991, see Whitney (1998, 91-118).

34 Early versions of this position may be found in Hick (1978); Peterson (1982); and Yandell (1989), and the view is given fuller defence in van Inwagen (1988 and 1991) and Hasker (1992).

35 This argument is connected to another challenge to theism known as the modal problem of evil. God is a traditionally held to be a necessary being - one who exists in all possible worlds. And it seems plausible to suppose that there are very bad possible worlds - ones that it would be morally impermissible for God to actualize. But if God is a necessary being who is the creator and sustainer of all that is, then in such worlds, God is responsible for their being actual. Since this is unacceptable, Guleserian (1983) claims, theists should either give up their belief in God, or dramatically revise their understanding of the divine attributes. In response, Morris (1987) urges that on theism, bad worlds are simply impossible, despite our 
modal intuitions and judgments to the contrary. Space does not permit an evaluation of this response, but for further discussion of this issue, see Garcia (1984); Tidman (1993); Almeida (unpublished manuscript); and Kraay (unpublished manuscript).

${ }^{36}$ But see Kretzmann’s (1991a) discussion of an alternative, Dionysian view.

37 See, for example, Helm (1988); Fales (1994); Menssen and Sullivan (1995); Mawson (2005); Wierenga (2002, 2007); and Senor (2008).

$3^{8}$ The contemporary discussion of this problem begins with Pike (1969). A survey of this literature is beyond the scope of this paper, but Wolf $(1998,409-416)$ includes a good list of contributions to this discussion up to 1996.

39 One representative critic is Grover 1993, and for an annotated bibliography of contributions to this debate up to 1991, see Whitney (1998, 61-90).

40 This is distinct from the problem of evil in several important respects. First, it proceeds entirely a priori, while arguments from evil generally contain at least one a posteriori premise about the existence, scope, or distribution of evil. Second, this argument concludes that an essentially unsurpassable God is impossible - a much stronger conclusion than arguments from evil can warrant. Third, this argument could still be advanced if evil were metaphysically impossible. It is an argument from improvability, rather than from evil.

${ }^{41}$ Wielenberg (2004) offers a defence of something like Principle B, using the virtue ethics of Hurka (2001).

${ }^{42}$ Leibniz unequivocally held this view:

For to think that God acts in anything without having any reason for his willing, even if we overlook the fact that such action seems impossible, is an opinion that conforms little to God's glory. For example, let us suppose that God chooses between A and B, and that he takes A without any reason for preferring it to B. I say that this action on the part of God is at least not praiseworthy, for all praise ought to be founded on the reason which ex hypothesi is not present there. My opinion is that God does nothing for which he does not deserve to be glorified" (Discourse on Metaphysics, 6-7).

43 Blumenfeld surveys Leibniz' arguments to this effect. For more on this charge, see Blumenfeld (1994, 396) and Donald Turner (2003, 147).

44 This strategy is endorsed by Quinn $(1982,206)$ and Strickland (2006). As Blumenfeld $(1975,174)$ and Grover $(2003,148)$ note, such a position is untenable if the principle of sufficient reason holds exceptionlessly.

45 Nicholas Rescher $(1969,156-7)$ maintains that it is absurd for God to use a randomizer, since, given his essential omniscience, God would foreknow the deliverances of any device or procedure used. The Howard-Snyders $(1994,266)$ and Strickland $(2006,151)$ reply that it is reasonable to suppose that there are no truths concerning the deliverances of randomizers, in which case there is no failure of omniscience here.

${ }^{46}$ Any such device, it should be noted, would be part of the world selected for actualization on the basis of that device's use. This will serve to fix certain parameters of that world: nothing logically inconsistent with the existence of this device could be part of the resulting world.

47 I assume, for simplicity, that all randomizers are commensurable and comparable with respect to a stable set of axiological properties. 
${ }^{48}$ Perhaps simplicity of construction or method is a good-making property of randomizers. Perhaps speed of operation is another. These properties both seem to have intrinsic maxima (of perfect simplicity and instantaneous operation), which might lead one to suppose that there is at least one unsurpassable randomizer. But to argue in this way requires being able to rule out the idea that possible randomizers asymptotically approach the relevant limits, and it requires showing that these two properties can be unsurpassably co-exemplified. These are considerable challenges.

49 One way to avoid these problems is to construct an account of random selection that does not involve the use of a randomizing device or procedure. For an argument against the plausibility of random worldselection accounts that rely on such devices or procedures, see Kraay ('Can God Choose a World at Random?', forthcoming).

\section{WORKS CITED}

Adams, R. 'Must God Create the Best?'. Philosophical Review 81 (1972): 317-332.

Almeida, M. ‘Theistic Modal Realism'. Unpublished Manuscript.

Basinger, D. 'In What Sense Must God Be Omnibenevolent?'. International Journal for Philosophy of Religion 14 (1983): 3-15.

'In What Sense Must God do His Best: A Response to Hasker'. International J ournal for Philosophy of Religion 18 (1985): 161-4.

Beaudoin, J. 'The World's Continuance: Divine Conservation or Existential Inertia'. International J ournal for Philosophy of Religion 61 (2007): 83-98.

Bergmann, M., and Cover, J.A. 'Divine Responsibility without Divine Freedom'. Faith and Philosophy 23 (2006): 381-408.

Blumenfeld, D. 'Is the Best World Possible?'. J ournal of Philosophy 84 (1975): 163-177.

'Perfection and Happiness in the Best Possible World'. The Cambridge Companion to Leibniz. Ed. N. Jolley. Cambridge: Cambridge University Press, 1994: 382-410.

Bosley, R.N. and M.M. Tweedale, eds. Basic Issues In Medieval Philosophy. Peterborough: Broadview, 2006.

Chrzan, K. 'The Irrelevance of the No Best Possible World Defence'. Philosophia 17 (1987): 161167.

Craig, W.L. 'Creation Ex Nihilo'. Process Theology. Ed. R. Nash. Grand Rapids: Baker Books, 1987, 141-176.

'Creation and Conservation Once More'. Religious Studies 34 (1998): 177-188.

Davis, R. The Metaphysics of Theism and Modality. New York: Peter Lang, 2001.

Davison, S.A. 'Could Abstract Objects Depend upon God?'. Religious Studies 27 (1991): 485-497. 
Elliot, R. 'Divine Perfection, Axiology, and the No Best World Defence'. Religious Studies 29 (1993): 533-542.

Fales, E. 'Divine Freedom and the Choice of a World'. International J ournal for Philosophy of Religion 35 (1994): 65-88.

Flint, T. 'The Problem of Divine Freedom'. American Philosophical Quarterly 20 (1983): 255264. Divine Providence: The Molinist Account, Cornell: Cornell University Press, 1989.

Ford, L. 'An Alternative to Creation Ex Nihilo'. Religious Studies 19 (1983): 204-219.

Forrest, P. ‘The Problem of Evil: Two Neglected Defences'. Sophia 20 (1981): 49-54.

Franklin, J. ‘Two Caricatures, II: Leibniz’s Best World’. Religious Studies 52 (2002): 45-56.

Freddoso, A.J. 'God's General Concurrence with Secondary Causes: Why Conservation is Not Enough'. Philosophical Perspectives 5 (1991): 553-585.

Gale, R. On The Nature and Existence of God, Cambridge: Cambridge University Press, 1991.

'R.M. Adams' Theodicy of Grace'. Philo 1 (1998): 36-44.

Ganssle, G.E. and D.M. Woodruff, eds. God and Time: Essays on the Divine Nature. Oxford: Oxford University Press, 2002.

Garcia, L. 'A Response to the Modal Problem of Evil'. Faith and Philosophy 1 (1984): 378-388. ‘Divine Freedom and Creation'. The Philosophical Quarterly 42 (1992): 191-213.

Gelinas, L. 'The Problem of Natural Evil (and Some Theistic Replies)'. Philosophy Compass, forthcoming.

Grover, S. 'Why only the Best is Good Enough'. Analysis 48 (1988): 224.

'Incommensurability and the Best of All Possible Worlds'. The Monist 81 (1998): 648667.

'Satisfied Pigs and Dissatisfied Philosophers: Schlesinger on the Problem of Evil'. Philosophical Investigations 16 (1993): 212-230.

'Mere Addition and the Best of All Possible Worlds'. Religious Studies 35 (1999): 173190.

'This World, 'Adams Worlds'. and the Best of All Possible Worlds'. Religious Studies 39 (2003): 145-163.

'Rival Creator Arguments and the Best of all Possible Worlds'. Sophia 43 (2004): 101114 . 
Guleserian, T. 'God and Possible Worlds: The Modal Problem of Evil'. Nous 17 (1983): 221-238.

Hasker, W. 'Must God do His Best?' International J ournal for Philosophy of Religion 16 (1984): 213-223.

'The Necessity of Gratuitous Evil'. Faith and Philosophy 9 (1992): 23-44.

'The Freedom and Goodness of God'. Providence, Evil, and The Openness of God. New York: Routledge, 2004, 166-186.

'Appendix: Replies to my Critics'. Providence, Evil, and The Openness of God. New York: Routledge, 2004, 202-206.

'Can God Be Free?: Rowe's Dilemma for Theology'. Religious Studies 41 (2005): 453462.

Heller, M. 'The Worst of All Worlds'. Philosophia 28 (2001): 255-268.

Helm, P. Eternal God. Oxford: Clarendon Press, 1988.

Hick, J. Evil and the God of Love. London: MacMillan Press, 1978.

Hoffman, J. and Rosenkrantz, G.S. The Divine Attributes. London: Blackwell, 2002.

Howard-Snyder, D, ed. The Evidential Argument from Evil. Indianapolis: Indiana University Press, 1996.

and Howard-Snyder, F. 'How an Unsurpassable Being can Create a Surpassable World'. Faith and Philosophy 11 (1994): 260-268.

'The Real Problem of No Best World'. Faith and Philosophy 13 (1996): 422-425.

Hurka, T. Virtue, Vice, and Value. Oxford: Oxford University Press, 2001.

Kant, I. Lectures on Philosophical Theology. Trans. A.W. Wood and G.M. Clark. Ithaca: Cornell University Press, 1978.

Kraay, K. 'Theistic Replies to the A Priori Argument for Atheism'. Philo 8 (2005): 28-36.

'Can God Choose a World at Random?'. New Waves in Philosophy of Religion, Eds. E. Weilenberg and Y. Nagasawa. Basingstoke: Palgrave MacMillan, forthcoming-a.

'The Problem of No Best World'. A Companion to Philosophy of Religion, Eds. C. Taliaferro and P. Draper. Oxford: Blackwell, forthcoming.

'Theism and Modal Collapse'. Unpublished Manuscript available at $<$ www.ryerson.ca/ kraay/>. 
Kretzmann, N. 'A General Problem of Creation: Why Would God Create Anything At All?'. Being and Goodness: The Concept of God in Metaphysics and Philosophical Theology. Ed. S.J. MacDonald. Ithaca: Cornell University Press, 1991, 208-228.

'A Particular Problem of Creation: Why Would God Create This World?'. Being and Goodness: The Concept of God in Metaphysics and Philosophical Theology. Ed. S.J. MacDonald. Ithaca: Cornell University Press, 1991, 229-249.

Kvanvig, J.L. and McCann, H.J. 'Divine Conservation and the Persistence of the World'. Divine and Human Action. Ed. T. Morris. Ithaca: Cornell University Press, 1988, 13-49.

Larrimore, M., ed. The Problem of Evil: A Reader. Oxford: Blackwell, 2001.

Langtry, B. 'God and the Best'. Faith and Philosophy 13 (1996): 311-328.

'God and Infinite Hierarchies of Creatable Worlds' Faith and Philosophy 23 (2006): 460-476.

Leftow, B. 'No Best World, Moral Luck'. Religious Studies 41 (2005): 165-181.

'No Best World, Creaturely Freedom'. Religious Studies 41 (2005): 269-285.

Leibniz, G.W. Discourse on Metaphysics. Trans. G. Montgomery. La Salle: Open Court, 1902. Theodicy. Ed. A. Farrer. Trans. E.M. Huggard. La Salle: Open Court, 1996.

Levine, M. 'Must God Create the Best?'. Sophia 35 (1996): 28-34.

Mackie, J.L. ‘Evil and Omnipotence’. Mind 64 (1955): 200-212.

Mann, W. 'The Best of all Possible Worlds'. Being and Goodness: The Concept of God in Metaphysics and Philosophical Theology. Ed. S.J. MacDonald. Ithaca: Cornell University Press, 1991, 251-277.

Mawson, T.J. 'Freedom, Human and Divine'. Religious Studies 41 (2005): 55-69.

McCann, H. 'Creation and Conservation'. A Companion to Philosophy of Religion. Eds. P.L. Quinn and C. Taliaferro. Oxford: Blackwell, 1997, 306-312.

Menssen, S. and Sullivan, T. 'Must God Create?' Faith and Philosophy 12 (1995): 321-341.

Morris, T. 'Creation Ex Nihilo: Some Considerations'. International J ournal for Philosophy of Religion 14 (1983): 227-240.

'The Necessity of God's Goodness', Anselmian Explorations: Essays in Philosophical Theology. Notre Dame: University of Notre Dame Press, 1987, 42-69.

'Perfection and Creation'. Reasoned Faith. Ed. E. Stump. Ithaca: Cornell University Press, 1993, 234-247. 
Perkins, R.K. 'An Atheistic Argument from the Improvability of the Universe'. Noûs 17 (1983): 239-250.

Peterson, M. Evil and the Christian God. Grand Rapids: Baker Book House, 1982.

Pike, N. 'Omnipotence and God's Ability to Sin'. American Philosophical Quarterly 6 (1969): 208-216.

Plato, Timaeus. Trans. B. Jowett. The Collected Dialogues of Plato, Including the Letters. Eds. E. Hamilton and H. Cairns. Princeton: Princeton University Press, 1987.

Plantinga, A. God, Freedom, and Evil. Grand Rapids: Eerdmans, 1974.

The Nature of Necessity. Oxford: Clarendon Press, 1974.

Warranted Christian Belief. Oxford: Oxford University Press, 2000.

Potter, R.C. 'How to Create a Physical Universe Ex Nihilo'. Faith and Philosophy 3 (1986): 1626.

Quinn, PL.. 'God, Moral Perfection, and Possible Worlds'. God: The Contemporary Discussion. Eds. F. Sontag and M.D. Bryant. New York: The Rose of Sharon Press, 1982, 197-213.

'Creation, Conservation, and the Big Bang'. Philosophical Problems of the Internal and External Worlds. Ed. J. Earman. Pittsburgh: University of Pittsburgh Press, 1983, 589612.

'Divine Conservation, Continuous Creation, and Human Action'. The Existence and Nature of God. Ed. A.J. Freddoso. Notre Dame: Notre Dame University Press, 1983, 5579.

Reichenbach, B. Evil and a Good God. New York: Fordham University Press, 1982.

Rescher, N. 'Choice Without Preference: A Study of the History and of the Logic of the Problem of 'Burdian's Ass”. Essays in Philosophical Analysis. Pittsburgh: University of Pittsburgh Press, 1969, 111-157.

Resnick, L. 'God and the Best Possible World'. American Philosophical Quarterly 10 (1973): 313-317.

Rowe, W. 'The Problem of Evil and Some Varieties of Atheism'. American Philosophical Quarterly 16 (1979): 335-341.

'The Problem of Divine Perfection and Freedom'. Reasoned Faith. Ed. E. Stump. Ithaca: Cornell University Press, 1993, 223-233.

'The Problem of No Best World'. Faith and Philosophy 11 (1994): 269-271.

‘Can God be Free?'. Faith and Philosophy 19 (2002): 405-424. 


\section{Can God Be Free?, Oxford: Oxford University Press, 2004.}

Schlesinger, G. Religion and Scientific Method, Dordrecht: Reidel, 1977.

Senor, T. 'Defending Divine Freedom'. Oxford Studies in Philosophy of Religion 1 (2008): 168195.

Sobel, J. H. Logic and Theism: Arguments for and Against Beliefs in God. Cambridge: Cambridge University Press, 2004.

Strickland, L. 'Determining the Best of All Possible Worlds'. The J ournal of Value Inquiry 39 (2005): 37-47. ‘God’s Problem of Multiple Choice’. Religious Studies 42 (2006): 141-157.

Swinburne, R. The Existence of God. Oxford: Oxford University Press, 1979.

Talbott, T. 'The Best of All Possible Worlds'. Unpublished Manuscript.

Taylor, J.E. 'Hume on Miracles: Interpretation and Criticism'. Philosophy Compass 2 (2007): 611-624.

Thomas, M.L. 'Robert Adams and the Best Possible World'. Faith and Philosophy 13 (1996): 252-259.

Tidman, P. ‘The Epistemology of Evil Possibilities'. Faith and Philosophy 10 (1993): 181-197.

Turner, D. 'The Many-Universes Solution to the Problem of Evil'. The Existence of God. Eds. R. Gale and A. Pruss. Aldershof: Ashgate, 2003, 143-159.

van Inwagen, P. 'The Magnitude, Duration, and Distribution of Evil: A Theodicy'. Philosophical Topics 16 (1988): 161-187.

'The Problem of Air, the Problem of Evil, the Problem of Silence'. Philosophical Perspectives 5: Philosophy of Religion. Ed. J.E. Tomberlin. Atascadero: Ridgeview Publishing Co., 1991, 135-165.

Wainwright, W. 'Jonathan Edwards, William Rowe, and the Necessity of Creation'. Faith Freedom and Rationality: Philosophy of Religion Today, Eds. J. Jordan and D. Howard-Snyder. Lanham: Roman \& Littlefield, 1996, 119-133.

'Rowe on God's Freedom and God's Grace'. Philo 8 (2005): 12-22.

Whitney, B. Theodicy: An Annotated Bibliography on the Problem of Evil, 1960-1991. Bowling Green: The Philosophy Documentation Center, 1998.

Wielenberg, E. 'A Morally Unsurpassable God Must Create the Best'. Religious Studies 40 (2004): 43-62.

Wierenga, E. 'The Freedom of God'. Faith and Philosophy 19 (2002): 425-436. 
'Perfect Goodness and Divine Freedom'. Philosophical Books 48 (2007): 207-216.

Wolf, R.G. Analytic Philosophy of Religion: A Bibliography, 1940-1991 Bowling Green: The Philosophy Documentation Center, 1998.

Yandell, K. ‘Gratuitous Evil and Divine Existence’. Religious Studies 25 (1989): 15-30. 